Utah State University

DigitalCommons@USU

Articles

Publications

$9-1-2015$

\title{
Unusual Behavior in Parental Care by a House Wren (Troglodytes aedon): Post Fledging Use of an Old Nest During Cold Nights
}

Micah N. Scholer

University of British Columbia

Follow this and additional works at: https://digitalcommons.usu.edu/sagestep_articles

Part of the Animal Sciences Commons, and the Plant Sciences Commons

\section{Recommended Citation}

Scholer, M.N. Unusual Behavior in Parental Care by a House Wren (Troglodytes aedon): Post Fledging Use of an Old Nest During Cold Nights. The Wilson Journal of Ornithology, 127(3), 545-547, (1 September 2015)

This Article is brought to you for free and open access by the Publications at DigitalCommons@USU. It has been accepted for inclusion in Articles by an authorized administrator of DigitalCommons@USU. For more information, please contact digitalcommons@usu.edu.

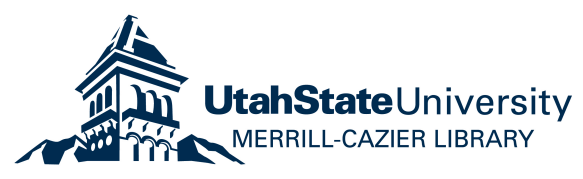




\title{
BioOne COMPLETE
}

\section{Unusual Behavior in Parental Care by a House Wren (Troglodytes aedon): Post Fledging Use of an Old Nest During Cold Nights}

\author{
Author: Scholer, Micah N.
}

Source: The Wilson Journal of Ornithology, 127(3) : 545-547

Published By: The Wilson Ornithological Society

URL: https://doi.org/10.1676/14-083.1

BioOne Complete (complete.BioOne.org) is a full-text database of 200 subscribed and open-access titles in the biological, ecological, and environmental sciences published by nonprofit societies, associations, museums, institutions, and presses.

Your use of this PDF, the BioOne Complete website, and all posted and associated content indicates your acceptance of BioOne's Terms of Use, available at www.bioone.org/terms-of-use.

Usage of BioOne Complete content is strictly limited to personal, educational, and non - commercial use. Commercial inquiries or rights and permissions requests should be directed to the individual publisher as copyright holder.

BioOne sees sustainable scholarly publishing as an inherently collaborative enterprise connecting authors, nonprofit publishers, academic institutions, research libraries, and research funders in the common goal of maximizing access to critical research. 


\title{
Unusual Behavior in Parental Care by a House Wren (Troglodytes aedon): Post Fledging Use of an Old Nest During Cold Nights
}

\author{
Micah N. Scholer ${ }^{1,2,3}$
}

\begin{abstract}
I report on the unusual behavior of an adult House Wren (Troglodytes aedon) leading recently fledged young back to the nest for two consecutive nights. The ambient temperature reached below $0^{\circ} \mathrm{C}$ during both nights. Despite disadvantages associated with remaining in the nest, this observation suggests that adult birds may assess trade-offs between perceived risks versus the benefits of engaging in other activities, in this case roosting communally for thermoregulation. Received 19 June 2014. Accepted 7 February 2015.
\end{abstract}

Key words: House Wren, nest predation, predation risk, thermoregulation, Troglodytes aedon.

High rates of nest predation in passerines may result in selection pressures that favor early departure of young from the nest (Martin 1995). Other factors, such as presence of nest ectoparasites, may provide additional drawbacks to chicks remaining in the nest (Sabrosky et al. 1989). Because of their poorly developed flight skills and, in some cases, inability to fully thermoregulate, fledglings may face increased vulnerability to predation and weather immediately following nest departure.

\section{OBSERVATIONS}

On 6 August 2013, I located a House Wrens' (Troglodytes aedon) nest containing five nestlings at an elevation of $1420 \mathrm{~m}$ in the Steens Mountain Cooperative Management and Protection Area $\left(42^{\circ} 38^{\prime} \mathrm{N}, 118^{\circ} 34^{\prime} \mathrm{W}\right)$ in southeast Harney County, Oregon. The nest was constructed in the rear of a pop-up tent trailer in a rolled length of canvas situated $0.8 \mathrm{~m}$ above the ground. I observed a single adult attending the nest, the sex of which I was unable to verify. Brood

\footnotetext{
${ }^{1}$ U.S. Geological Survey, Forest and Rangeland Ecosystem Science Center, 970 Lusk Street, Boise, ID 83706, USA.

${ }^{2}$ Department of Zoology and Biodiversity Research Centre, University of British Columbia, Vancouver, BC V6T 1Z4, Canada.

${ }^{3}$ Corresponding author; e-mail: micahscholer@gmail.com
}

desertion is common in House Wrens (Freed 1981), and I assumed the adult was acting as a solo parent and that its mate had either perished or abandoned the nest. As the trailer was used only occasionally, I was able to minimize disturbance to the nest while still monitoring the progress of the nestlings' development.

On 8 August 2013 at 1700 PST, I observed the adult giving a series of repeated "churr" calls near the nest. Over the next hour, the five nestlings fledged and joined their parent in a dense clump of western juniper (Juniperus occidentalis). Typically, House Wrens fledge before noon (Johnson et al. 2004) making this a rather late time of day for young to depart the nest. I monitored the fledglings continuously from 1800-1900 PST and measured the maximum distance that each was located from the nest using a Bushnell Sport 850 range-finder (Bushnell Outdoor Products, Overland Park, KS, USA). The fledglings remained close to the nest (7-12 m) and continued to be provisioned with food by the adult. At dusk, the adult perched above the nest entrance and again gave a series of repeated calls. The fledglings returned and entered the nest and were joined by the adult where they remained for the night. This series of behaviors recurred the following day when the adult repeatedly called and led the young farther away from the nest (90-104 $\mathrm{m}$ during continuous monitoring between 0530 and 0630 PST) then returned to the nest that evening and called until each of the five young were in the nest. The adult again joined the brood in the nest and remained there until the following morning. The next day the wren family left the nest and did not return. For each of three nights, I measured ambient temperature at 2000 PST. During both nights when the nest was reused, the temperature dropped below freezing to -2 and $-3{ }^{\circ} \mathrm{C}$, respectively. I measured temperature as $2{ }^{\circ} \mathrm{C}$ the first night that the wren family did not occupy the nest. 


\section{DISCUSSION}

Based on these observations, I suggest this behavior may reflect an assessment by the adult House Wren of trade-offs between associated risks of young remaining in the nest during night versus their thermoregulatory needs. First, because nest predation is the leading cause of reproductive failure in many bird species (e.g., an estimated $28.5 \%$ of House Wrens' nests fail because of predation), adults should minimize the amount of time nestlings spend in the nest if the risk of predation is high (Martin 1995). House Wrens effectively shorten the overall length of the nestling period, and hence reduce exposure of young to nest predators, by exhibiting asynchronous hatching without asynchronous fledging (Freed 1981). Under these circumstances, it is difficult to envision a situation where the parent would lead young back to the nest unless they perceived the risk of predation to be low. Indeed, the nest site location and presence of humans may have resulted in a relatively predator-free environment. Because the House Wrens' nest was located in a non-natural structure (i.e., tent trailer), it may not have been as easily identified by nest predators as a potential nest site location in the absence of behavioral cues (e.g., begging young, food deliveries by parents). My presence around the nest site may also have deterred potential nest predators. Predators may avoid areas where human activity is high, leading to spatial refuges from predation (Muhly et al. 2011). The time immediately after fledging may be more dangerous for young birds outside the nest than in it. Fledgling-survival estimates can range from 0.32 in migratory songbirds (Anders and Marshall 2005 ) to as low as 0.19 in some passerines (Rush and Stutchbury 2008). If recent fledglings have a more difficult time avoiding predators at night than during the day, then it may be beneficial to return to the nest while fledglings are still learning crucial flight skills. The absence of ectoparasites, many of which occur in nesting material and feed on the blood and tissue of nestlings primarily at night (Sabrosky et al. 1989), may have furthered influenced the wren's decision to return to the nest. Ectoparasites can have a profound effect on nestling survival by causing anemia, and therefore reducing the ability of young to sustain flight and evade predators after nest departure (O'Brien et al. 2001). If the nest had been heavily occupied by ectoparasites, it seems unlikely that the parent would have led young back to the nest or remained there themselves for the night. Finally, temperatures fell below freezing during the two nights that the nest was used after fledging. Although House Wrens are able to fully thermoregulate at fledging (Baldwin and Kendeigh 1932), communal roosting in birds can reduce energy costs (Beauchamp 1999), which could be critical for young fledglings.

Nest predation is a common limiting factor in the reproductive success of birds (Martin 1995) making nest sites potentially dangerous locations for young birds. Other factors, such as presence of ectoparasites, may provide additional incentives for leaving and remaining out of the nest. Life history theory predicts that adult birds can adjust their reproductive strategies to reflect apparent trade-offs between associated risks and the benefits gained from participating in an activity (Lima and Dill 1990). For instance, adult birds may reduce their reproductive effort when the perceived risk of predation to offspring is high (Martin and Briskie 2009, Fangyuan et al. 2014). Preble (1961) reported a similar incident in which an adult House Wren and its brood revisited a nest box post-fledging. Further observations will reveal whether such behavior is exhibited by other passerines when temperature conditions are cold and may lend support to explanations of variability in parental care behavior that are couched in terms of associated risks to offspring (Fontaine and Martin 2006, Fangyuan et al. 2014).

\section{ACKNOWLEDGMENTS}

I thank A. Baz for logistical support. Earlier drafts of this manuscript were improved by comments from S. E. Hanser, J. E. Jankowski, and two anonymous reviewers. This work was funded by the U.S. Joint Fire Sciences Program, the Bureau of Land Management, and the National Interagency Fire Center.

\section{LITERATURE CITED}

ANDERS, A. D. AND M. R. MARShall. 2005. Increasing the accuracy of productivity and survival estimates in assessing landbird population status. Conservation Biology 19:66-74.

Baldwin, S. P. And S. C. Kendeigh. 1932. Physiology of the temperature of birds. Scientific Publications of the Cleveland Museum of Natural History 3:1-196.

BeAuchamp, G. 1999. The evolution of communal roosting in birds: origin and secondary losses. Behavioral Ecology 10:675-687.

Fangyuan, H., K. E. Sieving, R. J. Fletcher JR., And C. A. WRIGHT. 2014. Increased perception of predation risk to adults and offspring alters avian reproductive 
strategy and performance. Behavioral Ecology 25:509-519.

Fontaine, J. J. AND T. E. MARTIN. 2006. Parent birds assess nest predation risk and adjust their reproductive strategies. Ecology Letters 9:428-434.

FreED, L. A. 1981. Breeding biology of House Wrens: new views of avian life history phenomena. Dissertation. University of Iowa, Iowa City, Iowa, USA.

Johnson, L. S., R. L. Rauch, And S. N. Dellone. 2004. The process and causes of fledging in a cavity-nesting passerine bird, the House Wren (Troglodytes aedon). Ethology 110:693-705.

LimA, S. L. AND L. M. DiLL. 1990. Behavioral decisions made under the risk of predation: a review and prospectus. Canadian Journal of Zoology 68:619640.

MARTIN, T. E. 1995. Avian life history evolution in relation to nest sites, nest predation, and food. Ecological Monographs 65:101-127.

Martin, T. E. AND J. V. BriskiE. 2009. Predation on dependent offspring: a review of the consequences for mean expression and phenotypic plasticity in avian life history traits. Annals of the New York Academy of Science 1168:201-217.

Muhly, T. B., C. Semeniuk, A. Massolo, L. Hickman, AND M. MUSIANI. 2011. Human activity helps prey win the predator-prey space race. PLoS One 6:e17050.

O'BriEn, E. L., B. L. MORRISON, AND L. S. JOHNSON. 2001. Assessing the effects of haematophagous ectoparasites on the health of nestling birds: haematocrit vs haemoglobin levels in House Wrens parasitized by blow fly larvae. Journal of Avian Biology 32:73-76.

Preble, C. S. 1961. Unusual behavior of House Wren. Auk 78:442.

Rush, S. A. AND B. J. M. Stutchbury. 2008. Survival of fledgling Hooded Warblers (Wilsonia citrina) in small and large forest fragments. Auk 125:183-191.

SAbrosky, C. W., G. F. BennetT, And T. L. Whitworth. 1989. Bird blow flies (Protocalliphora) in North America (Diptera: Calliphoridae), with notes on the Palearctic species. Smithsonian Institution Press, Washington, DC, USA.

\title{
The Correct Name of the Curl-crested Aracari (Pteroglossus beauharnaisii) and the Date of Its Publication
}

\author{
Rick Wright ${ }^{1,2}$
}

\begin{abstract}
The original description and name of the aracari currently known as Pteroglossus beauharnaesii Wagler 1832 have been inexplicably overlooked. By priority, the correct name and author citation is in fact Pteroglossus beauharnaisii Wagler 1831. Received 15 October 2014. Accepted 24 February 2015.
\end{abstract}

Key words: aracaris, Curl-crested Aracari, Johann Georg Wagler, nomenclature, Pteroglossus beauharnaisii, Pteroglossus beauharnaesii, toucans.

On his return from South America in 1829, Auguste Charles Eugène Napoléon de Beauharnais (1810-1835), duke of Leuchtenberg and prince of Eichstätt, brought with him a vast range of natural history specimens for incorporation into his private museum (Wagler 1831a, b). The Brazilian material was reviewed by Johann Georg Wagler (1800-1832), director of the zoological museum at the University of Munich; Wagler

\footnotetext{
${ }^{1} 128$ Evans Road, Bloomfield, NJ 07003, USA.

${ }^{2}$ Corresponding author; e-mail: birdaz@gmail.com
}

found much that he thought was new, especially among the birds on display in the young duke's Naturalienkabinett.

Among the nova was a small toucan, "exceedingly remarkable for the bizarre feather structure on its head" (Wagler 1832:280; translation RW), which Wagler resolved to name for Duke Auguste. Unfortunately, an error was introduced into the description published in the Isis for 1832, and the bird was assigned the species epithet "Beauharnaesii," a regrettable misspelling of the duke's family name, even if an understandable one from the hands of a German typesetter.

Even more unfortunately, that error-in spite of its rectification by Sturm and Sturm (1841-1847) and in the 1850 Conspectus generum avium of Auguste's cousin by marriage Charles Bonaparte-has been continually repeated in catalogues and other works ever since. It is perpetuated today in all of the important world and regional checklists (Peters 1948, Monroe and Sibley 1997, 